\title{
Effect of the high-pressure-release phase on the protein composition of the soluble milk fraction
}

\author{
F. I. Bravo, E. Molina, and R. López-Fandiño' \\ Instituto de Investigación en Ciencias de la Alimentación (CIAL), CSIC-UAM, 28049 Madrid, Spain
}

\begin{abstract}
This paper describes a study on the influence of the high-pressure-release rate on the protein distribution between the soluble and colloidal fractions of milk. Skim milk, without or with sulfhydryl-blocking agents, was pressure treated at 250 and $350 \mathrm{MPa}$ for 5 to 15 min at $25^{\circ} \mathrm{C}$, applying different pressure-release rates (pressure-release times between 0.07 to $10 \mathrm{~min}$ ). The liberation of caseins to the soluble phase and the denaturation of whey proteins were assessed. A significantly higher increase in the content of soluble casein took place during the pressure-release phase as compared with a pressure-holding phase. Denaturation of $\beta$-lactoglobulin mainly took place by -SH-S-S exchange reactions during the holding phase. The present results, thus, show a negligible influence of whey proteins on the increase in the content of nonsedimentable casein in pressure-treated milk and provide evidence for the importance of the pressure-release rate in this process, so that the slower the pressure release rate, the higher the level of soluble casein.
\end{abstract}

Key words: high-pressure-release rate, milk protein, high-pressure treatment, protein distribution

\section{INTRODUCTION}

The properties of casein micelles in high-pressuretreated milk related to their size, number, composition, and hydration are different from those of raw or heated milk (Huppertz et al., 2006a; López-Fandiño, 2006). High-pressure treatment brings about the disintegration of casein micelles, which can subsequently reaggregate under certain conditions. The extent of these changes depends on different factors, such us pressure level, holding time, temperature, calcium content, and pH, among others (Arias et al., 2000; García-Risco et al., 2000; Huppertz et al., 2004a). Furthermore, high pressure also denatures whey proteins, which may as-

Received February 29, 2012.

Accepted July 29, 2012.

${ }^{1}$ Corresponding author: rosina.lopez@csic.es sociate with casein micelles or micellar fragments, and some studies have dealt with the interaction between both phenomena (Huppertz et al., 2004b; Anema et al., 2005a; Huppertz and de Kruif, 2007).

Although the pressure buildup rate has been reported to have no significant influence on the pressure-induced modification of caseins (Merel-Rausch et al., 2006), the pressure-release rate appears as a factor largely ignored in most high-pressure studies. However, previous results obtained in our laboratory show that the pressurerelease rate could be of major importance in terms of micellar disintegration and casein solubilization, as well as in whey protein denaturation (unpublished results). According to Fertsch et al. (2003), the firmness of pressure-induced gels made at $600 \mathrm{MPa}$ from micellar casein solutions depends on the decompression rate, so that the faster the pressure release, the finer the microstructure and the firmer the gels. These authors suggested that once the pressure-holding time brings about the dissociation of the casein micelles, a slow pressure-release rate allows the development of casein hyperstructures, due to the reformation of calcium bridges and hydrophobic interactions, which interfere with homogeneous gelling (Fertsch et al., 2003). MerelRausch et al. (2007) also found less-firm gels at slow pressure-release rates. In this case, the increase in the viscosity of $5 \%$ micellar casein solutions, submitted to 400 and $600 \mathrm{MPa}$ at 20 and $30^{\circ} \mathrm{C}$ and fast pressurerelease rates $(600 \mathrm{MPa} / \mathrm{min})$, was correlated with the formation of loose and large aggregated structures that build from smaller casein micelles. Thus, high pressurerelease rates $(600 \mathrm{MPa} / \mathrm{min})$ would lead to large hydrodynamic diameters, whereas low pressure-release rates $(20 \mathrm{MPa} / \mathrm{min})$ would decrease the hydrodynamic diameter with respect to control milk (Merel-Rausch et al., 2006). In this respect, the influence of whey protein denaturation on pressure-induced casein dissociation or reaggregation is not yet clear (Huppertz et al., 2006a; López-Fandiño, 2006).

In view of the importance that the physicochemical properties of milk proteins have on its technological quality, our aim was to study the influence of the pressure-release rate on the protein distribution between the soluble and colloidal fractions of high-pressure- 
treated milk. For this purpose, skim milk, without or with a sulfhydryl-blocking agent, was pressure treated at 250 and $350 \mathrm{MPa}$ for 5 to $15 \mathrm{~min}$ at $25^{\circ} \mathrm{C}$, applying different pressure-release times between 0.07 to $10 \mathrm{~min}$. The extent of casein liberation to the soluble phase and the influence of whey protein denaturation on this process were assessed.

\section{MATERIALS AND METHODS}

\section{Sample Preparation}

Raw bovine milk was collected from a local farm. The milk was skimmed by heating at $37^{\circ} \mathrm{C}$ for $30 \mathrm{~min}$, centrifugation at $3,000 \times g$ for $30 \mathrm{~min}$ at $20^{\circ} \mathrm{C}$ in a Sorvall Evolution RC centrifuge (Kendro Laboratory Products GmbH, Hanau, Germany), and filtering through glass wool.

Skim milk was treated with N-ethylmaleimide (NEM; Sigma-Aldrich, St. Louis, MO), according to Needs et al. (2000), to block protein sulfhydryl groups involved in whey protein denaturation. N-Ethylmaleimide is insoluble in water, so it was dissolved in dimethyl formamide (DMF; Lab-Scan, Gliwice, Poland) at a concentration of $20 \mathrm{mg} / \mathrm{mL}$ and $16.7 \mathrm{~mL} / \mathrm{L}$ was added to skim milk. Samples with the same volume of DMF added were used as controls. All NEM- and DMF-added samples were incubated overnight at $20^{\circ} \mathrm{C}$ before the pressure treatments.

\section{High-Pressure Treatments}

Samples were poured into $70-\mathrm{mL}$ polyethylene bottles, leaving no headspace, and pressurized at 250 or $350 \mathrm{MPa}$ and $25^{\circ} \mathrm{C}$ in an ACB $900 \mathrm{HP}$ apparatus (Eurotherm Automation SAS, Lyon, France), with water as a pressure transmitting medium. To assess the effect of the holding time at each pressure level, the pressure was raised at a rate of $2.5 \mathrm{MPa} / \mathrm{s}$; maintained for 5,6 , 10 , or $15 \mathrm{~min}$; and released in $0.07 \mathrm{~min}(4 \mathrm{~s})$; that is, at pressure release rates of 62.5 and $87.5 \mathrm{MPa} / \mathrm{s}$ for treatments at 250 and $350 \mathrm{MPa}$, respectively. To assess the effect of the pressure-release rate, the pressure was increased at a rate of $2.5 \mathrm{MPa} / \mathrm{s}$, maintained for 5 min, and released in $0.07,1,5$, or $10 \mathrm{~min}$. That is, for treatments at $250 \mathrm{MPa}$, the pressure release rates were $62.5,4.2,0.8$, or $0.4 \mathrm{MPa} / \mathrm{s}$ and, at $350 \mathrm{MPa}, 87.5,5.8$, 1.2 , or $0.6 \mathrm{MPa} / \mathrm{s}$, respectively. In the next sections, the pressure-release times will be used as an indicator of the different pressure-release rates to simplify the presentation of the results. All high-pressure treatments were performed at least in duplicate.

\section{Protein Fractions for Analysis}

Ultracentrifugation supernatants were obtained from high-pressure-treated skim milk samples by ultracentrifugation at $100,000 \times g$ for $1 \mathrm{~h}$ at $20^{\circ} \mathrm{C}$ in a Beckman L70 preparative ultracentrifuge (Beckman Instruments Inc., San Ramon, CA), using a type $70 \mathrm{Ti}$ rotor, and the supernatants were filtered through Whatman No. 41 filter paper. Fractions soluble at $\mathrm{pH} 4.6$ were obtained by dropwise addition of $2 \mathrm{M} \mathrm{HCl}$ under continuous stirring, followed by a 20 -min standing period at room temperature, centrifugation at $4,000 \times g$ and $20^{\circ} \mathrm{C}$ for $30 \mathrm{~min}$, and filtration through Whatman No. 40 filter paper.

\section{Analyses of Milk and Protein Fractions}

Determination of Protein Content. The total protein content was determined by the Kjeldahl method, according to the reference procedure published by the International Dairy Federation (FIL-IDF, 1993). In the case of samples with sulfhydryl-blocking agents, the nitrogen content due to the amount of NEM and DMF added was subtracted before its conversion into protein.

Capillary Electrophoresis. Capillary electrophoresis separations were performed using a Beckman P/ACE System 2050 and a TSP-coated fused-silica capillary (BGB Analytik Vertrieb, Schloßböckelheim, Germany) of $57 \mathrm{~cm}$ (effective length of $50 \mathrm{~cm}$ ), $0.50 \mu \mathrm{m}$ i.d., and slit opening of $100 \times 800 \mu \mathrm{m}$, at $45^{\circ} \mathrm{C}$, with a linear gradient from 0 to $25 \mathrm{kV}$ in $3 \mathrm{~min}$, followed by a constant voltage of $25 \mathrm{kV}$ for $47 \mathrm{~min}$. The injection time was $60 \mathrm{~s}$ and detection was at $214 \mathrm{~nm}$. Protein identification and quantification was carried out according to Recio et al. (1997).

\section{Statistical Analysis}

Results from 2 independent experiments were expressed as mean values \pm standard deviation and were analyzed by a one-way ANOVA to test the influence of the holding time and the pressure-release time and by a 2-way ANOVA to test the interaction between both factors. Statgraphics Plus 5.0 for Windows software was used for data processing (Statistical Graphics Corp., Princeton, NJ; http://www.statgraphics.com).

\section{RESULTS}

The contents of nonsedimentable protein and $\mathrm{pH}$ 4.6-soluble protein of milk high-pressure-treated at 250 and $350 \mathrm{MPa}$ were determined. Table 1 shows the effect of the holding time with $0.07 \mathrm{~min}$ of depressurization 
Table 1. Protein contents $(\mathrm{g} / \mathrm{L} \pm \mathrm{SD}$ ) of the ultracentrifugation supernatants (US) and $\mathrm{pH}$ 4.6-soluble fractions (SP) of control skim milk (0 holding and pressure-release times) and milk pressurized at 250 and $350 \mathrm{MPa}$ and $25^{\circ} \mathrm{C}$ at different holding and pressure-release times

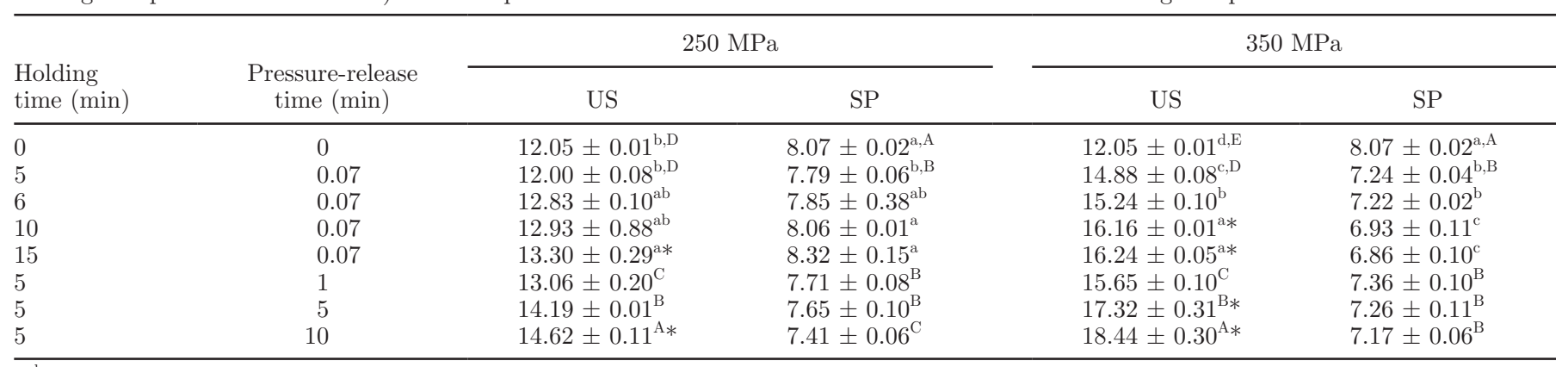

${ }^{\mathrm{a}-\mathrm{d}}$ Different lowercase superscript letters within a column indicate significant differences $(P<0.05)$ produced by the holding time.

${ }^{\mathrm{A}-\mathrm{E}}$ Different uppercase superscript letters within a column indicate significant differences $(P<0.05)$ produced by the pressure-release time. *Indicates the existence of significant differences $(P<0.05)$ between equivalent values corresponding to the same total treatment times with different combinations of holding and pressure-release times at each pressure level.

and the effect of the depressurization time with $5 \mathrm{~min}$ of holding time.

At $250 \mathrm{MPa}$, the levels of nonsedimentable proteins were similar to that of the control milk at holding times $<15 \mathrm{~min}$, whereas at $350 \mathrm{MPa}$, they significantly increased with holding times $\geq 5$ min (Table 1 ). The contents of whey proteins soluble at $\mathrm{pH} 4.6$ significantly decreased after $5 \mathrm{~min}$ at 250 and $350 \mathrm{MPa}$, and the holding time at $350 \mathrm{MPa}$ up to $15 \mathrm{~min}$ also exerted a significant lowering effect $(P<0.05)$.

As compared with the fastest depressurization $(0.07$ min), an increase in the pressure-release time (from 1 to $10 \mathrm{~min}$ ) significantly increased the levels of nonsedimentable proteins at both pressure levels and, particularly, at $350 \mathrm{MPa}$ (Table 1). Total treatment times of $15 \mathrm{~min}$ at 250 and 10 and $15 \mathrm{~min}$ at $350 \mathrm{MPa}$ led to significantly higher contents of soluble proteins when the holding time was $5 \mathrm{~min}$, with 5 and $10 \mathrm{~min}$ of depressurization, than when the holding times were 10 and $15 \mathrm{~min}$, respectively, with $0.07 \mathrm{~min}$ of depressurization. However, the pressure-release time and the pressure-holding time exerted a similar influence on the contents of proteins soluble at $\mathrm{pH} 4.6$ after treatments at 250 and $350 \mathrm{MPa}$ (Table 1 ).

The analysis by capillary electrophoresis of the individual contents of $\alpha-\mathrm{LA}$ and $\beta-\mathrm{LG}$ present in the fractions soluble at $\mathrm{pH} 4.6$ of the pressure-treated samples showed that, both at 250 and $350 \mathrm{MPa}$, the holding time had no effect on the denaturation of $\alpha$-LA (not shown), but promoted the denaturation of $\beta-L G$, particularly at $350 \mathrm{MPa}$ (Figure 1a). In addition, $\beta$-LG denaturation was significantly higher $(P<0.05)$ after holding times of 6,10 , or $15 \mathrm{~min}$ followed by $0.07 \mathrm{~min}$ of release time, than after holding times of $5 \mathrm{~min}$ followed by 1,5 , or $10 \mathrm{~min}$ of pressure-release time (Figure 1 a and $b)$.
The contents of the individual proteins present in the ultracentrifugation supernatants were analyzed by capillary electrophoresis (Tables 2 and 3). As an example, Figure 2 shows the electropherograms corresponding to samples pressure treated at $350 \mathrm{MPa}$. At equivalent treatment times, the levels of virtually all individual caseins were significantly $(P<0.05)$ higher when treatments for $5 \mathrm{~min}$ at 250 and $350 \mathrm{MPa}$ were followed by 5 and 10 min of depressurization than when milk was subjected to each pressure level for 10 and $15 \mathrm{~min}$, but no differences were observed between the levels of nonsedimentable $\alpha$-LA or $\beta$-LG (Tables 2 and 3 ).

As shown in Table 4, the hindrance of disulfideexchange reactions by the addition of NEM did not affect high-pressure-induced protein solubilization, which took place at a higher extent after long depressurization times as compared with long holding times to achieve equivalent treatment times with fast depressurization (0.07 min). On the other hand, as expected, the addition of NEM to milk as a sulfhydryl-blocking agent prevented whey protein denaturation at $350 \mathrm{MPa}$. The experiments with DMF, in which NEM was dissolved, added to milk, consistently showed the higher effect of the pressure-release time on protein solubilization. However, no significant differences were observed in whey protein denaturation between the holding time and the pressure-release time.

\section{DISCUSSION}

According to the present results, considerably large releases of nonsedimentable caseins to the serum phase occurred at 250 and, particularly, at $350 \mathrm{MPa}$, with the pressure-release time having a greater effect on casein solubilization than the holding time for equivalent treatment times (Tables 1-3; Figure 2). Pressure- 

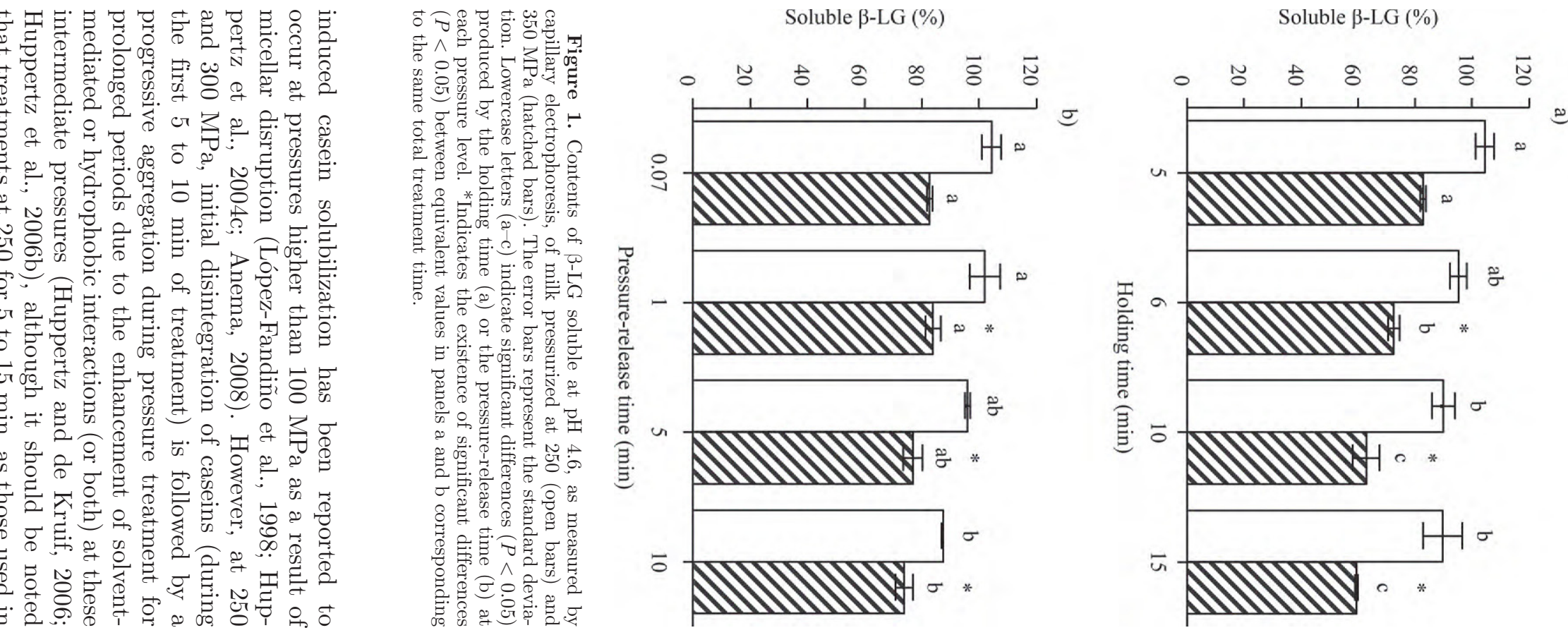

\section{$\cong$}

Table 2. Individual proteins present in the ultracentrifugation supernatants control skim milk ( 0 holding and pressure-release times) and milk pressurized at $250 \mathrm{MPa}$ and $25^{\circ} \mathrm{C}$ at different holding and pressure-release times

\begin{tabular}{|c|c|c|c|c|c|c|c|c|c|c|}
\hline Item & $\begin{array}{l}\text { Pressure-release } \\
\text { time (min) }\end{array}$ & $\alpha-\mathrm{LA}$ & $\beta-\mathrm{LG}$ & $\alpha_{\mathrm{S2}^{-}} \mathrm{CN}$ & $\alpha_{\mathrm{S1}_{1}-\mathrm{CN}}$ & $\alpha_{\mathrm{S}_{1}-\mathrm{CN}} 9 \mathrm{P}$ & $\kappa-\mathrm{CN}$ & $\beta_{\mathrm{B}^{-}} \mathrm{CN}$ & $\beta_{\mathrm{A} 1}-\mathrm{CN}$ & $\beta_{\mathrm{A}^{2}-\mathrm{CN}}$ \\
\hline \multicolumn{11}{|c|}{ Holding time ( $\min )$} \\
\hline 0 & 0 & $107.93^{\mathrm{a}, \mathrm{A}}$ & $101.34^{\mathrm{a}, \mathrm{A}}$ & $15.05^{\mathrm{a}, \mathrm{B}}$ & $13.30^{\mathrm{c}, \mathrm{D}}$ & $14.96^{\mathrm{c}, \mathrm{D}}$ & $23.19^{\mathrm{a}, \mathrm{C}}$ & $28.88^{\mathrm{a}, \mathrm{C}}$ & $16.98^{\mathrm{b}, \mathrm{D}}$ & $21.39^{\mathrm{b}, \mathrm{D}}$ \\
\hline 5 & 0.07 & $108.47^{\mathrm{a}, \mathrm{A}}$ & $96.24^{\mathrm{a}, \mathrm{A}}$ & $15.78^{\mathrm{a}, \mathrm{B}}$ & $17.09^{\mathrm{b}, \mathrm{CD}}$ & $20.70^{\mathrm{ab}, \mathrm{C}}$ & $26.57^{\mathrm{a}, \mathrm{BC}}$ & $23.16^{\mathrm{a}, \mathrm{C}}$ & $17.15^{\mathrm{b}, \mathrm{D}}$ & $19.20^{\mathrm{c}, \mathrm{E}}$ \\
\hline 6 & 0.07 & $102.96^{\mathrm{a}}$ & $93.93^{\mathrm{a}}$ & $17.41^{\mathrm{a}}$ & $20.00^{\mathrm{a}}$ & $22.49^{\mathrm{a}}$ & $30.12^{\mathrm{a}}$ & $32.72^{\mathrm{a}}$ & $21.82^{\mathrm{a}}$ & $23.99^{\mathrm{a}}$ \\
\hline 10 & 0.07 & $105.97^{\mathrm{a}}$ & $93.74^{\mathrm{a}}$ & $18.24^{\mathrm{a}}$ & $17.74^{\mathrm{b} *}$ & $19.28^{\mathrm{b}} *$ & $28.91^{\mathrm{a} *}$ & $30.54^{\mathrm{a}}$ & $19.37^{\mathrm{ab} *}$ & $23.59^{\mathrm{a} *}$ \\
\hline 15 & 0.07 & $98.91^{\mathrm{a}}$ & $90.72^{\mathrm{a}}$ & $21.52^{\mathrm{a}}$ & $16.57^{\mathrm{b} *}$ & $17.74^{\mathrm{bc} *}$ & $27.51^{\mathrm{a} *}$ & $25.43^{\mathrm{a}}$ & $18.52^{\mathrm{b} *}$ & $21.14^{\mathrm{b} *}$ \\
\hline 5 & 1 & $96.59^{\mathrm{A}}$ & $91.00^{\mathrm{A}}$ & $18.77^{\mathrm{AB}}$ & $18.38^{\mathrm{C}}$ & $20.91^{\mathrm{C}}$ & $31.93^{\mathrm{B}}$ & $27.45^{\mathrm{BC}}$ & $20.17^{\mathrm{C}}$ & $23.05^{\mathrm{C}}$ \\
\hline 5 & 5 & $96.91^{\mathrm{A}}$ & $93.05^{\mathrm{A}}$ & $19.45^{\mathrm{AB}}$ & $24.11^{\mathrm{B} *}$ & $26.62^{\mathrm{B} *}$ & $37.96^{\mathrm{A} *}$ & $33.26^{\mathrm{AB}}$ & $24.65^{\mathrm{B} *}$ & $27.99^{\mathrm{B} *}$ \\
\hline 5 & 10 & $109.36^{\mathrm{A}}$ & $101.56^{\mathrm{A}}$ & $26.01^{\mathrm{A}}$ & $29.31^{\mathrm{A} *}$ & $33.10^{\mathrm{A} *}$ & $46.62^{\mathrm{A} *}$ & $35.23^{\mathrm{A}}$ & $30.71^{\mathrm{A} *}$ & $31.23^{\mathrm{A} *}$ \\
\hline Pooled SD ${ }^{2}$ & & 3.65 & 3.28 & 2.34 & 0.57 & 0.86 & 2.51 & 3.18 & 0.71 & 0.33 \\
\hline Pooled SD ${ }^{3}$ & & 3.52 & 3.46 & 2.66 & 1.18 & 1.22 & 1.54 & 1.66 & 0.60 & 0.29 \\
\hline
\end{tabular}

${ }^{\mathrm{a}-\mathrm{c}}$ Different lowercase superscript letters within a column indicate significant differences $(P<0.05)$ produced by the holding time.

${ }^{\text {A-E }}$ Different uppercase superscript letters within a column indicate significant differences $(P<0.05)$ produced by the pressure-release time.

${ }^{1}$ Values are expressed as percentages of the content of each individual casein in control skim milk, estimated by capillary electrophoresis.

${ }^{2}$ Pooled SD of the values corresponding to control milk and samples pressurized for 5, 6, 10, and 15 min and depressurized in 0.07 min.

${ }^{3}$ Pooled SD of the values corresponding to control milk and samples pressurized for 5 min and depressurized in $0.07,1,5$, and 10 min.

*Indicates the existence of significant differences $(P<0.05)$ between equivalent values corresponding to the same total treatment times with different combinations of holding and pressure-release times at each pressure level. 

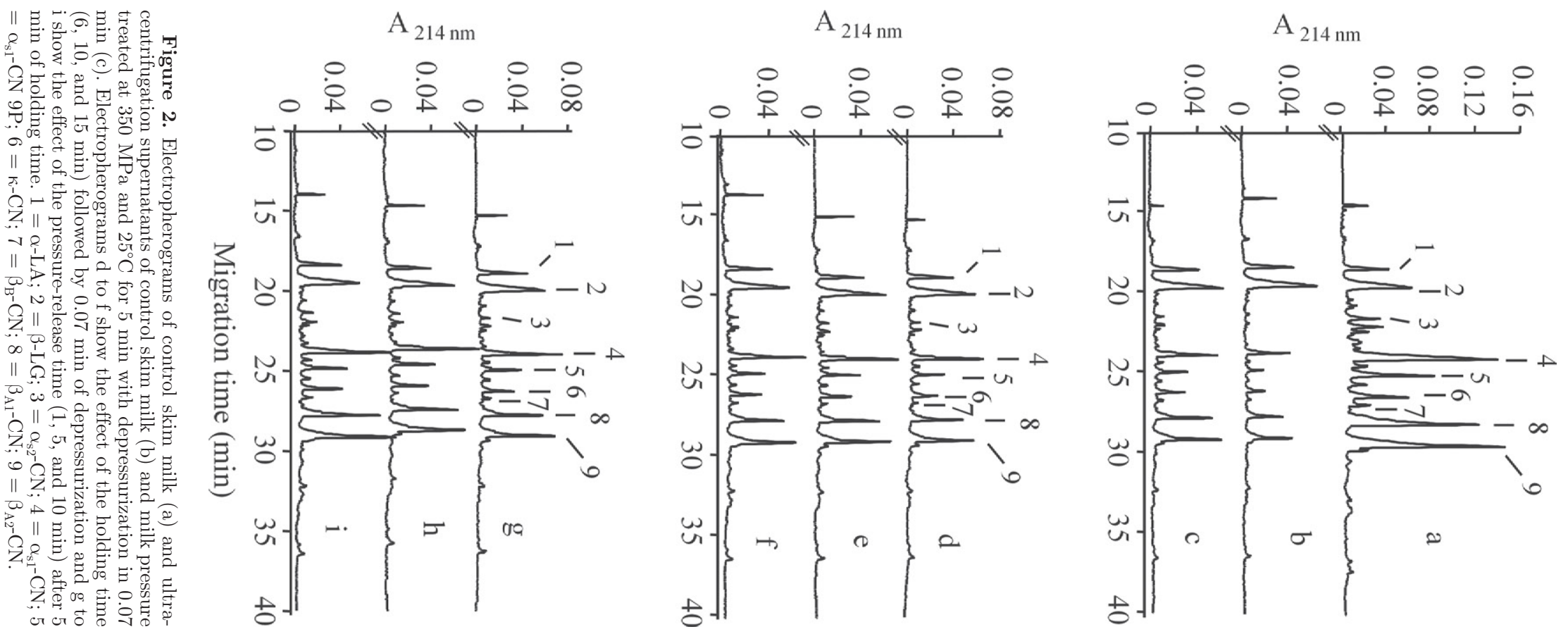

Table 3. Individual proteins present in the ultracentrifugation supernatants control skim milk ( 0 holding and pressure-release times) and milk pressurized at $350 \mathrm{MPa}$ and $25^{\circ} \mathrm{C}$ at different holding and pressure-release times

\begin{tabular}{|c|c|c|c|c|c|c|c|c|c|c|}
\hline Item & $\begin{array}{l}\text { Pressure-release } \\
\quad \text { time (min) }\end{array}$ & $\alpha-L A$ & $\beta-\mathrm{LG}$ & $\alpha_{\mathrm{S} 2}-\mathrm{CN}$ & $\alpha_{\mathrm{S1}^{-}} \mathrm{CN}$ & $\alpha_{\mathrm{S}^{-}} \mathrm{CN} 9 \mathrm{P}$ & $\kappa-\mathrm{CN}$ & $\beta_{\mathrm{B}^{-}} \mathrm{CN}$ & $\beta_{\mathrm{Al}^{-}} \mathrm{CN}$ & $\beta_{\mathrm{A} 2^{-}} \mathrm{CN}$ \\
\hline \multicolumn{11}{|c|}{ Holding time (min) } \\
\hline 0 & 0 & $107.93^{\mathrm{a}, \mathrm{A}}$ & $101.34^{\mathrm{a}, \mathrm{B}}$ & $15.05^{\mathrm{b}, \mathrm{B}}$ & $13.30^{\mathrm{d}, \mathrm{D}}$ & $14.96^{\mathrm{b}, \mathrm{D}}$ & $23.19^{\mathrm{c}, \mathrm{D}}$ & $24.88^{\mathrm{b}, \mathrm{C}}$ & $16.98^{\mathrm{c}, \mathrm{D}}$ & $21.39^{\mathrm{c}, \mathrm{C}}$ \\
\hline 5 & 0.07 & $102.61^{\mathrm{a}, \mathrm{A}}$ & $90.57^{\mathrm{ab}, \mathrm{A}}$ & $29.18^{\mathrm{a}, \mathrm{A}}$ & $25.34^{\mathrm{c}, \mathrm{C}}$ & $27.19^{\mathrm{a}, \mathrm{C}}$ & $33.89^{\mathrm{b}, \mathrm{CD}}$ & $35.91^{\mathrm{a}, \mathrm{B}}$ & $25.93^{\mathrm{b}, \mathrm{C}}$ & $29.75^{\mathrm{b}, \mathrm{B}}$ \\
\hline 6 & 0.07 & $100.53^{\mathrm{a}}$ & $88.61^{b c}$ & $27.66^{\mathrm{a}}$ & $26.88^{\mathrm{bc}}$ & $29.57^{\mathrm{a}}$ & $37.94^{\mathrm{ab}}$ & $37.76^{\mathrm{a}}$ & $26.82^{\mathrm{b}}$ & $29.58^{\mathrm{b}}$ \\
\hline 10 & 0.07 & $95.85^{\mathrm{a}}$ & $78.33^{\mathrm{c}}$ & $29.75^{\mathrm{a}}$ & $29.64^{\mathrm{ab}}$ & $26.86^{\mathrm{a}}$ & $40.51^{\mathrm{a}}$ & $34.66^{\mathrm{a} *}$ & $29.66^{\text {a* }}$ & $32.56^{\mathrm{ab} *}$ \\
\hline 15 & 0.07 & $91.26^{\mathrm{a}}$ & $79.73^{\mathrm{bc}}$ & $32.17^{\mathrm{a}}$ & $30.29^{\mathrm{a} *}$ & $30.72^{\mathrm{a} *}$ & $40.97^{\mathrm{a} *}$ & $37.45^{\mathrm{a} *}$ & $31.19^{\mathrm{a} *}$ & $36.07^{\mathrm{a} *}$ \\
\hline 5 & 1 & $97.93^{\mathrm{A}}$ & $88.62^{\mathrm{A}}$ & $30.73^{\mathrm{A}}$ & $28.52^{\mathrm{BC}}$ & $29.56^{\mathrm{BC}}$ & $38.64^{\mathrm{BC}}$ & $37.48^{\mathrm{B}}$ & $30.01^{\mathrm{C}}$ & $35.07^{\mathrm{B}}$ \\
\hline 5 & 5 & $100.77^{\mathrm{A}}$ & $88.41^{\mathrm{A}}$ & $31.24^{\mathrm{A}}$ & $32.51^{\mathrm{B}}$ & $33.92^{\mathrm{AB}}$ & $49.35^{\mathrm{AB}}$ & $45.97^{\mathrm{A} *}$ & $37.70^{\mathrm{B} *}$ & $43.06^{\mathrm{A} *}$ \\
\hline 5 & 10 & $99.89^{\mathrm{A}}$ & $88.00^{\mathrm{A}}$ & $35.33^{\mathrm{A}}$ & $37.91^{\mathrm{A} *}$ & $39.31^{\mathrm{A} *}$ & $53.49^{\mathrm{A} *}$ & $49.00^{\mathrm{A} *}$ & $44.18^{\mathrm{A} *}$ & $48.18^{\mathrm{A} *}$ \\
\hline Pooled SD ${ }^{2}$ & & 4.65 & 3.13 & 2.17 & 0.87 & 2.17 & 1.76 & 2.38 & 0.46 & 1.42 \\
\hline Pooled SD ${ }^{3}$ & & 3.79 & 1.82 & 2.30 & 1.23 & 1.31 & 3.14 & 2.22 & 1.20 & 1.90 \\
\hline \multicolumn{11}{|c|}{ 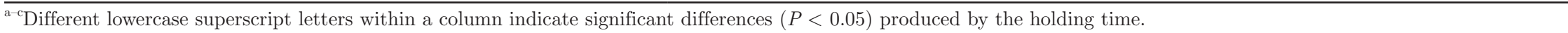 } \\
\hline \multicolumn{11}{|c|}{${ }^{\mathrm{A}-\mathrm{D}}$ Different uppercase superscript letters within a column indicate significant differences $(P<0.05)$ produced by the pressure-release time. } \\
\hline \multicolumn{11}{|c|}{${ }^{1}$ Values are expressed as percentages of the content of each individual casein in control skim milk, estimated by capillary electrophoresis. } \\
\hline \multicolumn{11}{|c|}{${ }^{2}$ Pooled SD of the values corresponding to control milk and samples pressurized for $5,6,10$, and 15 min and depressurized in 0.07 min. } \\
\hline \multicolumn{11}{|c|}{${ }^{3}$ Pooled SD of the values corresponding to control milk and samples pressurized for 5 min and depressurized in $0.07,1,5$, and 10 min. } \\
\hline \multicolumn{11}{|c|}{$\begin{array}{l}\text { *Indicates the existence of significant differences }(P<0.05) \text { between equivalent values corresponding to the same total treatment times with different combinations of holding and } \\
\text { pressure-release times at each pressure level. }\end{array}$} \\
\hline
\end{tabular}


Table 4. Protein contents (\% of total milk protein \pm SD) of the ultracentrifugation supernatants (US) and pH 4.6-soluble fractions (SP) of control skim milk (0 holding and pressure-release times) and milk pressurized at $350 \mathrm{MPa}$ and $25^{\circ} \mathrm{C}$ at different holding and pressure-release times $^{1}$

\begin{tabular}{|c|c|c|c|c|c|}
\hline $\begin{array}{l}\text { Holding } \\
\text { time (min) }\end{array}$ & $\begin{array}{l}\text { Pressure-release } \\
\text { time (min) }\end{array}$ & \multicolumn{2}{|c|}{ US } & \multicolumn{2}{|c|}{$\mathrm{SP}$} \\
\hline 0 & 0 & $32.41 \pm 2.47^{\mathrm{b}, \mathrm{C}}$ & $32.41 \pm 0.96^{\mathrm{c}, \mathrm{C}}$ & $21.08 \pm 4.1^{\mathrm{a}, \mathrm{A}}$ & $24.85 \pm 0.67^{\mathrm{a}, \mathrm{A}}$ \\
\hline 10 & 0.07 & $38.74 \pm 3.33^{\mathrm{a} *}$ & $39.57 \pm 2.60^{\mathrm{b} *}$ & $20.86 \pm 3.50^{\mathrm{a}}$ & $21.00 \pm 0.71^{\mathrm{b}}$ \\
\hline 15 & 0.07 & $39.03 \pm 0.18^{\mathrm{a} *}$ & $44.76 \pm 0.18^{\mathrm{a} *}$ & $20.64 \pm 0.71^{\mathrm{a}}$ & $21.00 \pm 0.47^{\mathrm{b}}$ \\
\hline 5 & 5 & $50.78 \pm 1.80^{\mathrm{A} *}$ & $51.62 \pm 0.82^{\mathrm{A} *}$ & $20.64 \pm 0.39^{\mathrm{A}}$ & $22.30 \pm 0.90^{\mathrm{B}}$ \\
\hline
\end{tabular}

${ }^{a-c}$ Different lowercase superscript letters within a column indicate significant differences $(P<0.05)$ produced by the holding time.

${ }^{\mathrm{A}-\mathrm{C}}$ Different uppercase superscript letters within a column indicate significant differences $(P<0.05)$ produced by the pressure-release time.

*Indicates the existence of significant differences $(P<0.05)$ between equivalent values corresponding to the same total treatment times with different combinations of holding and pressure-release times at each pressure.

${ }^{1} \mathrm{NEM}=\mathrm{N}$-ethylmaleimide; DMF $=$ dimethyl formamide

the present study, might be too short to induce micellar reformation (Huppertz and de Kruif, 2007). Moreover, the aggregation of the casein-depleted micellar particles that maintain a certain degree of integrity and some intact colloidal calcium phosphate, mainly due to the reestablishment of hydrophobic bonds, once pressure has been liberated, has been reported (Huppertz et al., 2006b; Orlien et al., 2006; Anema, 2008).

Although pressure-disrupted electrostatic and hydrophobic bonds may start to reform while high pressure is released, our results clearly showed that a significantly higher increase in the content of nonsoluble casein took place during the pressure-release phase as compared with the pressure-holding phase. According to MerelRausch et al. (2006, 2007), the pressure-release rate, at pressures higher than $200 \mathrm{MPa}$, is important for casein modification because slow release rates would favor casein reassociation, whereas fast pressure-release rates would disturb self-association mechanisms, building up completely new structures or aggregates. In principle, substantial levels of dissociated casein could be compatible with a situation that promotes micellar reaggregation. In fact, high levels of nonsedimentable caseins are found in the case the aggregated samples formed at pressures of 250 to $300 \mathrm{MPa}$ (Anema et al., 2005a), an observation that suggests that the aggregation of casein-depleted micelles takes place as a separate event from what causes micellar disruption, even if a minimum level of micellar disruption seems to be required for aggregation to occur (Huppertz and de Kruif, 2006; Anema, 2008).

The present results support previous findings that indicate that $\beta$-LG denatures at pressures higher than $100 \mathrm{MPa}$ to an extent that depends on the pressure level and the duration of the treatment (López-Fandiño et al., 1996; Anema et al., 2005b). Reversible unfolding of $\beta-L G$, exposure of the hydrophobic regions and of the free -SH group under pressure can be followed by irreversible denaturation, whether self aggregation or association with other whey proteins or with $\kappa$-CN (López-Fandiño et al., 1997; Needs et al., 2000; Patel et al., 2006). The observation that, in milk pressurized at 250 and $350 \mathrm{MPa}$, a proportion of denatured $\beta$-LG remained soluble at the normal milk pH (Figure 1; Tables 2 and 3) has also been made by other authors (LópezFandiño et al., 1998; Anema, 2008), and suggests that $\beta$-LG molecules preferentially self-associate or interact with nonsedimentable casein particles. Our results (Table 1 ; Figure 1) indicate that $\beta$-LG denatured mainly due to disulfide linkages during the pressure-holding phase, under conditions of high solubility of calcium phosphate and inhibition of hydrophobic interactions, because little additional denaturation took place during the decompression phase. This supports that the -SHS-S exchange reactions mainly take place during the pressure treatment (Belloque et al., 2000), suggesting that the hydrophobic bonds that may reform during the pressure-release phase do not play a major role in $\beta$-LG denaturation.

The present results also suggest a negligible influence of the whey proteins on the increase in the content of nonsedimentable casein that occurred during the depressurization phase, as this was not accompanied by further changes in the levels of whey proteins present in the ultracentrifugal supernatants (Tables 2 and 3) nor by an increased whey protein denaturation, as determined by the loss of solubility at $\mathrm{pH} 4.6$ (Table 1 ; Figure 1). As expected, the addition of NEM prevented disulfide bond formation, avoiding most whey protein denaturation and association with caseins (Huppertz et al., 2004d), but it did not have any effect on the release of protein to the soluble phase of milk that took place during the decompression phase (Table 4). Similarly, pressure-induced changes in micellar size are probably 
independent of the whey proteins, because similar micellar sizes are reported in high-pressure-treated milk with or without NEM added (Huppertz et al., 2004b). Furthermore, micellar disaggregation and reaggregation have been found to occur at 250 and $300 \mathrm{MPa}$ to comparable extents in the absence or presence of whey proteins (Anema et al., 2005a; Huppertz and de Kruif, 2007).

\section{ACKNOWLEDGMENTS}

This work received financial support from the project Consorcios Estratégicos Nacionales de Investigación Técnica (CENIT)-2007-2016 Futural, Ingenio Program. F. I. Bravo acknowledges the Autonomous Community of Madrid (Spain) for the contract of researching supporting personnel through the project ALIBIRD-CMS-505/AGR-0153.

\section{REFERENCES}

Anema, S. G. 2008. Effect of milk solids concentration on whey protein denaturation, particle size changes and solubilization of casein in high-pressure-treated skim milk. Int. Dairy J. 18:228-235.

Anema, S. G., E. K. Lowe, and R. Stockmann. 2005a. Particle size changes and casein solubilisation in high-pressure-treated skim milk. Food Hydrocoll. 19:257-267.

Anema, S. G., R. Stockmann, and E. K. Lowe. 2005b. Denaturation of $\beta$-lactoglobulin in pressure-treated skim milk. J. Agric. Food Chem. 53:7783-7791.

Arias, M., R. López-Fandiño, and A. Olano. 2000. Influence of pH on the effects of high pressure on milk proteins. Milchwissenschaft 55:191-194.

Belloque, J., R. López-Fandiño, and G. M. Smith. 2000. A ${ }^{1} \mathrm{H}-\mathrm{NMR}$ study on the effect of high pressures on $\beta$-lactoglobulin. J. Agric. Food Chem. 48:3906-3912.

Fertsch, B., M. Müller, and J. Hinrichs. 2003. Firmness of pressureinduced casein and whey protein gels modulated by holding time and rate of pressure release. Innov. Food Sci. Emerg. Technol. 4:143-150.

FIL-IDF (International Dairy Federation). 1993. Milk. Determination of nitrogen content (Kjeldahl method). Standard 20B. International Dairy Federation, Brussels, Belgium.

García-Risco, M. R., A. Olano, M. Ramos, and R. López-Fandiño. 2000. Micellar changes induced by high pressure. Influence in the proteolytic activity and organoleptic properties of milk. J. Dairy Sci. 83:2184-2189.

Huppertz, T., and K. G. de Kruif. 2006. Disruption and reassociation of casein micelles during high pressure: Influence of milk se- rum composition and casein micelle concentration. J. Agric. Food Chem. 54:5903-5909.

Huppertz, T., and K. G. de Kruif. 2007. Disruption and reassociation of casein micelles during high pressure treatment: Influence of whey proteins. J. Dairy Res. 74:194-197.

Huppertz, T., P. F. Fox, K. G. de Kruif, and A. L. Kelly. 2006a. High pressure-induced changes in bovine milk proteins: A review. Biochim. Biophys. Acta 1764:593-598.

Huppertz, T., P. F. Fox, and A. L. Kelly. 2004a. High pressure treatment of bovine milk: Effects of casein micelles and whey proteins. J. Dairy Res. 71:97-106.

Huppertz, T., P. F. Fox, and A. L. Kelly. 2004b. Properties of casein micelles in high pressure-treated bovine milk. Food Chem. $87: 103-110$

Huppertz, T., P. F. Fox, and A. L. Kelly. 2004c. Dissociation of caseins in high pressure-treated bovine milk. Int. Dairy J. 14:675-680.

Huppertz, T., P. F. Fox, and A. L. Kelly. 2004d. High pressure-induced denaturation of $\alpha$-lactalbumin and $\beta$-lactoglobulin in bovine milk and whey: A possible mechanism. J. Dairy Res. 71:489-495.

Huppertz, T., A. L. Kelly, and K. G. de Kruif. 2006b. Disruption and reassociation of casein micelles under high pressure. J. Dairy Res. 73:294-298.

López-Fandiño, R. 2006. High pressure-induced changes in milk proteins and possible applications in dairy technology. Int. Dairy J. 16:1119-1131

Lopez-Fandiño, R., A. V. Carrascosa, and A. Olano. 1996. The effects of high pressure on whey protein denaturation and cheese-making properties of raw milk. J. Dairy Sci. 79:929-936.

López-Fandiño, R., M. A. de la Fuente, M. Ramos, and A. Olano. 1998. Distribution of minerals and proteins between the soluble and colloidal phases of pressurized milks from different species. J. Dairy Res. 65:69-78.

López-Fandiño, R., M. Ramos, and A. Olano. 1997. Rennet coagulation of milk subjected to high pressure. J. Agric. Food Chem. 45:3233-3237.

Merel-Rausch, E., I. P. Duma, and J. Hinrichs. 2006. Pressure-induced modification of casein micelles-Influence of pressure built-up rate, pressure level, release rate and temperature on viscosity and particle size. Milchwissenschaft 61:255-259.

Merel-Rausch, E., U. Kulozik, and J. Hinrichs. 2007. Influence of pressure release rate and protein concentration on the formation of pressure-induced casein structures. J. Dairy Res. 74:283-289.

Needs, E. C., R. A. Stenning, A. L. Gill, V. Ferragut, and G. T. Rich. 2000. High-pressure treatment of milk: Effects on casein micelle structure and on enzymatic coagulation. J. Dairy Res. 67:31-42.

Orlien, V., J. C. Knudsen, M. Colon, and L. H. Skibsted. 2006. Dynamics of casein micelles in skim milk during and after high pressure treatment. Food Chem. 98:513-521.

Patel, H. A., H. Singh, S. G. Anema, and L. K. Creamer. 2006. Effects of heat and high hydrostatic pressure treatments on disulfide bonding interchanges among the proteins in skim milk. J. Agric. Food Chem. 54:3409-3420.

Recio, I., L. Amigo, M. Ramos, and R. López-Fandiño. 1997. Application of capillary electrophoresis to the study of proteolysis of caseins. J. Dairy Res. 64:221-230. 